\title{
The Classification of 'Bacterium salmonicida'
}

\author{
By ISABEL W. SMITH \\ Marine Laboratory, Aberdeen*
}

(Received 9 April 1963)

\begin{abstract}
SUMMARY
Forty-two strains of 'Bacterium salmonicida', six of a non-pigmented fish pathogen and forty-two Aeromonas strains were compared morphologically, culturally, biochemically and metabolically. The results, which were computed electronically, showed a distinct difference between ' $B$. salmonicida' and the Aeromonas species. On the grounds of this variation in morphology, culture and biochemistry, it is suggested that ' $B$. salmonicida' be removed from the genus Aeromonas and given a generic place in the family Pseudomonadaceae. The name Necromonas salmonicida is suggested as an alternative to ' $\mathrm{B}$. salmonicida'.
\end{abstract}

\section{INTRODUCTION}

The causal organism of furunculosis of the Salmonidae was originally called 'Bacterium salmonicida' (Lehmann \& Neumann, 1896), though Marsh (1902) later cited it as ' $B$. trutta'. Since its systematic position is in doubt, the former name will be used here, though it is an illegitimate name. Recently, however, some workers, including Griffin, Snieszko \& Friddle (1953a), Eddy (1960, 1962), Ewing, Hugh \& Johnson (1961), and Schubert (1961), have classified the organism as one of the genus Aeromonas. The strains of this organism isolated at the Marine Laboratory, Aberdeen, did not fall into the genus Aeromonas when classified according to Skerman (1957) because of weak gas production from glucose. Several strains of this organism have now been collected and examined to determine whether they belong to the same species and are in fact members of the genus Aeromonas. The organisms were compared with another fish pathogen and some organisms belonging to the genus Aeromonas.

\section{METHODS}

Strains. The cultures of 'Bacterium salmonicida' and other organisms were obtained from the sources shown in Table 1 . All the cultures were incubated at $22^{\circ}$ unless otherwise stated, and all the results were replicated. One loopful from a 2-day nutrient broth culture was used as the inoculum.

Morphology. Two-day and 7-day cultures in nutrient broth and on blood agar were examined by phase-contrast microscopy for size, shape, granulation and configuration, and the same cultures were examined after staining by Gram's method. Motilities were examined in 2-day peptone water cultures and preparations from 2-day nutrient agar slopes stained by Kirkpatrick's method were examined for the presence of flagella.

* Present address: Bacteriology Department, University of Edinburgh, Teviot Place, Edinburgh 8. 
Cultural characteristics. The growth on Yeastrel agar of the following composition: Oxoid Lab-lemco, 5 g.; Yeastrel, 7 g.; Difco peptone, 9.5 g.; NaCl, 5 g.; Davis agar, $30 \mathrm{~g}$.; distilled water, $1000 \mathrm{ml}$.; $\mathrm{pH} \mathrm{7.0}$ and that in nutrient broth was recorded at 2 and 7 days. All the cultures were inoculated into peptone water and examined for flocculation after incubation for 7 days at $5^{\circ}$.

Table 1. The sources of the organisms used in this survey

\begin{tabular}{|c|c|c|c|}
\hline No. & Source & Date & Donor \\
\hline $0-9$ & $\begin{array}{l}\text { Salmo salar and } S . \text { trutta, Scottish } \\
\text { waters }\end{array}$ & 1960 & - \\
\hline 10 & S. salar, R. Itchen & 1960 & $\begin{array}{l}\text { Dr M. H. Hughes, P.H.L., } \\
\text { Winchester }\end{array}$ \\
\hline 11 & S. salar, Bournemouth & 1960 & $\begin{array}{l}\text { Dr G. J. G. King, P.H.L., } \\
\text { Bournemouth }\end{array}$ \\
\hline $12-18$ & $S$. salar and $S$. trutta, Exeter area & 1960 & Dr W. J. Ryan, P.H.L., Exeter \\
\hline 19 & S. salar, R. Wye & 1954 & NCTC 9378 \\
\hline 20-25 & S. salar, Welsh rivers & $\begin{array}{l}1959 \\
1960\end{array}$ & $\begin{array}{l}\text { The Director, P.H.L., } \\
\text { Carmarthen }\end{array}$ \\
\hline $26-27$ & Coregonus pollan, Lough Neagh & 1960 & K. U. Vickers, Min. Commerce, Belfast \\
\hline $28-29$ & Bonashamm & 1959 & Dr O. Ljungberg, Stockholm \\
\hline 30-31 & Esox lucius, Minnesota & 1959 & Dr P. Economon, Minnesota \\
\hline 32-33 & $\begin{array}{l}\text { Oncorhynchus kisutch and } O . \\
\text { tscharoytscha, U.S.A. }\end{array}$ & 1960 & Dr J. W. Wood, Seattle \\
\hline $34-40$ & $\begin{array}{l}\text { Salmo and Oncorhynchus spp. U.S.A. } \\
\text { NCMB } 833-839 . \text { CDC RH } 39,40,67-69 \text {, } \\
72,78\end{array}$ & - & Dr J. M. Shewan, Aberdeen \\
\hline 41 & American strain E.в. 382 & - & Dr O. Lysenko, Czeckoslovakia \\
\hline $42-75$ & $\begin{array}{l}\text { S. salar, S. trutta and Perca perca, } \\
\text { Scottish waters }\end{array}$ & $\begin{array}{l}1959 \\
1960\end{array}$ & - \\
\hline $76-81$ & S. trutta, Scottish waters & 1961 & - \\
\hline $82-86$ & $\begin{array}{l}\text { Human and animal sources (Ewing } \\
\text { et al. } 1961 \text { ), NCIB } 9233,9237,9238 \text {, } \\
9239,9240\end{array}$ & - & Dr J. M. Shewan, Aberdeen \\
\hline $\mathbf{8 7}-\mathbf{9 0}$ & $\begin{array}{l}\text { Human sources (Caselitz \& Günther } \\
\text { 1960), NCIB 9244, 9245, 9248, 9249 }\end{array}$ & - & Dr J. M. Shewan, Aberdeen \\
\hline
\end{tabular}

Carbohydrate utilization in peptone medium. The fermentation of carbohydrates was examined in $1 \%$ Difco peptone water with Andrade's indicator. The media were sterilized by Tyndallization and the gas production recorded as positive when more than one-tenth of the liquid in a Durham tube was displaced by gas. For a comparison of gas production in the presence of different peptones and from glucose sterilized by filtration and in buffered peptone, standard $50 \mathrm{~mm}$. Durham tubes were used. The displacement of gas was measured to the nearest $0.5 \mathrm{~mm}$. and the volumes expressed as a percentage. Hugh \& Leifson's medium (1953) was used to determine the method of carbohydrate metabolism. The lactose sugars were read at 7 and 40 days; the remainder of the sugar tests were read only at 7 days.

The following tests were carried out as described by Mackie \& McCartney (1960) unless otherwise stated.

Methyl red and Voges-Proskauer tests were performed in 7-day glucose phosphate peptone water cultures. Acetylmethylcarbinol was detected by Barritt's modification.

Indole production was tested by adding Ehrlich's rosindol reagent to 7-day peptone water cultures.

Nitrate reduction. After incubation for 7 days, Griess-Ilosvay reagents were added to nitrate broth cultures (Topley \& Wilson's Principles, 1946). 
Hydrogen sulphide production was tested with lead acetate strips and ZoBell \& Feltham agar (1934).

Urease activity was studied in 7-day cultures in Christensen's agar (Christensen, 1946).

Ammonia production from peptone. Nessler's reagent was added to 2-day peptone water cultures (Topley \& Wilson's Principles, 1946).

Catalase activity was tested by emulsifying a loopful of 2-day nutrient agar culture in 20 vol. hydrogen peroxide (Sneath, 1956).

Oxidase activity was tested by Kovacs method (1956).

Haemolysis and caseinolysin were tested on Eddy's medium (1960).

Liquefaction of coagulated serum was tested on Loeffler's medium after 14 days.

Liquefaction of gelatin was recorded after 7 days in nutrient gelatin.

Litmus milk was examined at daily intervals up to 14 days for acid production, clotting, proteolysis and reduction of litmus.

Aesculin hydrolysis was tested on the medium of Sneath (1956) after 4 days.

Phosphatase activity was tested on Barber \& Kuper's medium (1951) after 2 days.

Starch hydrolysis was tested on nutrient agar containing $0 \cdot 4 \%$ starch by flooding the plate with Lugol's iodine after incubation for 1 day.

Lecithinase production in egg-yolk medium was examined on Esselman \& Liu's medium (1961) at 14 days.

Presumptive test for 'Bacterium salmonicida'. Griffin, Snieszko \& Friddle (1953b) cultured organisms on a Trypticase-Yeastrel agar for $18 \mathrm{hr}$. On flooding the growth with $p$-phenylenediamine the development of a black coloration was taken as indicative of the presence of 'B. salmonicida'. The test was carried out as described by the authors above.

Growth in citrate was recorded after 7 days in Koser's medium.

Gluconate oxidation was tested by the method of Sneath (1956).

Production of 2,3-butanediol was determined after 1, 3 and 7 days' growth in glucose medium by Bullock's method (1961).

Phenylalanine and malonate tests were done by the method of Shaw \& Clarke (1955).

Cellulase activity was estimated by the digestion of filter-paper strips in halfstrength peptone water after 7 days (Skerman, 1957, see p. 1019).

Sensitivity to antibiotics. Evans Senstests were applied to the seeded surface of nutrient agar plates and the results read after incubation for 1 day. The vibriostatic agent, 0-129 (Shewan, Hodgkiss \& Liston, 1954) was incorporated in filterpaper discs and applied to the agar and read as above.

Growth at different temperatures was examined on solid media and the results recorded after 1 day at $22^{\circ}$ and $37^{\circ}$ and after 7 days at $5^{\circ}$.

Growth in various salt concentrations was examined in peptone water with 1,3 and $8 \% \mathrm{NaCl}$ after 7 days' incubation.

Computation of the results. The results were tabulated, omitting the thirty features which were identical for all the strains examined. One hundred and eight features were treated as alternatives and three as quantitative ones. The statistical relationship was calculated by Mr J. C. Gower, who used the Rothamsted computer programme (Elliott 401 Computer programme F 39, Rothamsted Experimental Station, 
1960). The formula for the similarity $S_{i j}$ of two strains $i$ and $j$ is expressed as follows.

$$
S_{i j}=\frac{t_{i j}}{n_{i j}} \times 100,
$$

where $t_{i j}$ is the total number of positive and negative matches and $n_{i j}$ is the total number of features compared for the two strains $i$ and $j$.

\section{RESULTS}

When the results were computed, it was found that they split into two definite groups at $S=75$ ( $\mathrm{Mr}$ Gower, personal communication). These consisted of $(a)$ organisms $0-41$ and $76-81$, and $(b) 42-75$ and $82-90$; i.e. the pigmented and nonpigmented 'Bacterium salmonicida' formed group a and the Aeromonas strains group b. Increasing the $S$ value divided the organisms further until, at $S=90$, the five groups shown in Fig. 1 emerged. As can be seen in Fig. 1 the strains have been rearranged and from now on the groups will not be expressed in numerical sequence, but in the rearranged order found in Fig. 1. Group I, 77-79, corresponded to the non-pigmented fish pathogen recently described and thought to be an achromogenic

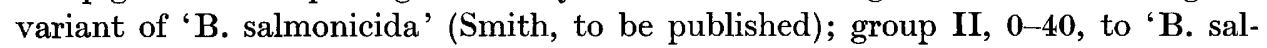
monicida' and groups III, 48, 71; IV, 83-86; and V, 66-65, to the Aeromonas strains. The mean similarities of each group of organisms were calculated and these are shown in Table 2. It is evident that each group has a high similarity within itself (except in the case of group V). Groups I and II have a similarity to each other of $76 \%$, while only one of $47 \cdot 5-64 \%$ to the other three groups. Likewise the latter three groups have a similarity of almost $70 \%$ to each other.

Table 2. The mean similarities of the groups

\begin{tabular}{|c|c|c|c|c|c|}
\hline Nos. & $\begin{array}{c}\text { Group I } \\
77-79\end{array}$ & $\begin{array}{c}\text { Group II } \\
0-40\end{array}$ & $\begin{array}{c}\text { Group III } \\
48,71\end{array}$ & $\begin{array}{c}\text { Group IV } \\
83-86\end{array}$ & $\underset{66-65}{\text { Group V }}$ \\
\hline Group I & $95 \cdot 6$ & - & - & - & - \\
\hline Group II & $75 \cdot 6$ & $92 \cdot 1$ & - & - & - \\
\hline Group III & $47 \cdot 5$ & $51 \cdot 3$ & 94.3 & - & - \\
\hline Group IV & $55 \cdot 1$ & $64 \cdot 0$ & $76 \cdot 0$ & $90 \cdot 6$ & - \\
\hline Group V & $59 \cdot 0$ & $63 \cdot 0$ & 68.9 & $77 \cdot 9$ & $77 \cdot 1$ \\
\hline
\end{tabular}

Table 3. The mean similarities of the subgroups of Group IV

$\begin{array}{ccccc} & \text { Group IVa } & \text { Group IVb } & \text { Group IVc } & \text { Group IVd } \\ \text { Nos. } & \mathbf{8 3 - 8 7} & \mathbf{4 9 - 8 4} & 47-90 & 43-86 \\ \text { Group IVa } & \mathbf{9 7 \cdot 2 5} & - & - & - \\ \text { Group IVb } & \mathbf{8 8 . 3 5} & \mathbf{9 3 . 9 6} & - & - \\ \text { Group IV c } & \mathbf{8 6 . 9 0} & \mathbf{8 9 \cdot 2 2} & \mathbf{9 0 \cdot 3 3} & - \\ \text { Group IVd } & \mathbf{8 0 \cdot 8 0} & \mathbf{8 1 . 8 3} & \mathbf{8 1 \cdot 5 9} & \mathbf{8 5 \cdot 2 3}\end{array}$

The intra-group similarities for each member of groups I and II were calculated and they were found to lie between 93.5 and $95.8 \%$ in group I and 87.2 and $94.6 \%$ in group II. In group II all but 7 of the $\mathbf{4 2}$ strains had a mean similarity of $90 \%$ or over.

Groups I and II do not resolve further but group IV can be subdivided into 4 groups as shown in Table 3. Group IV a consisted of 3 NCIB cultures but none of the other groups showed any homogeneity with regard to source or pathogenicity. 


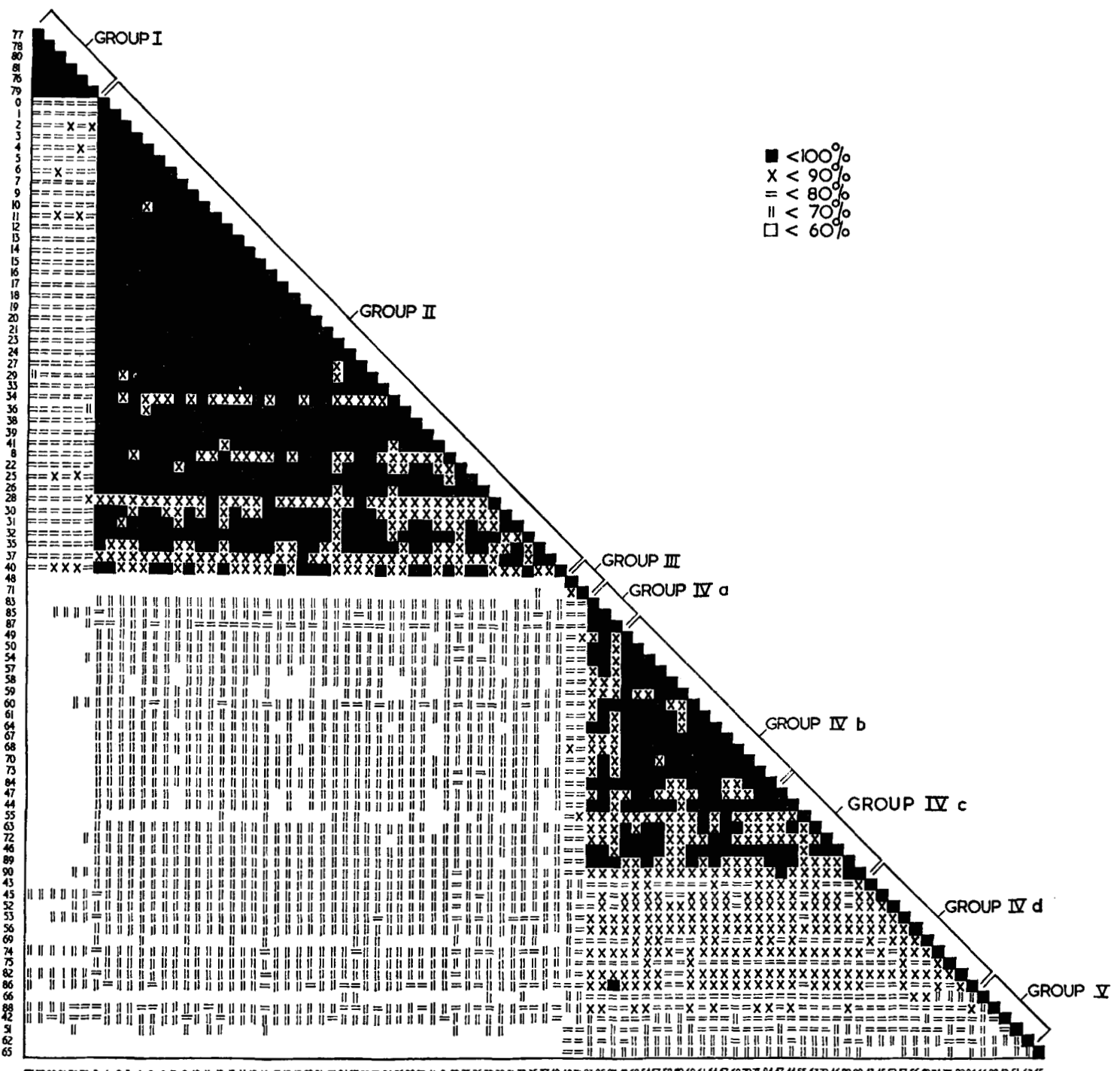

Fig. 1. Diagram of the relationship of the 91 strains used in the survey.

Table 4. The average percentage of liquid displaced by gas in Durham tube

Peptone Difco Oxoid Evans Difeo Difco Difco

$\begin{array}{lllll}\text { Sugar T.G. T.G. T.G. T. T. T. T.G. } & \text { T. T. }\end{array}$

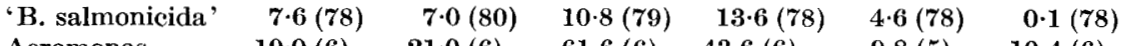

$\begin{array}{lllllll}\text { Aeromonas } & 19 \cdot 0(6) & 21 \cdot 0(6) & 61 \cdot 6(6) & 43.6(6) & 9 \cdot 8(5) & 10 \cdot 4(6)\end{array}$

T.G., Tyndallized glucose; T.M., Tyndallized mannitol; F.G., Filtered glucose; B.G., buffered glucose. Numbers in parentheses denote the number of tests. 
The gas production of 'Bacterium salmonicida' in glucose and mannitol was compared with that of the group IV Aeromonas strains. The results in Table 4 show that, in Difco peptone, 'B. salmonicida' produced less than $10 \%$ gas when the glucose medium was Tyndallized and even less when the glucose was Seitz-filtered or the medium buffered with $1 \%$ phosphate. Oxoid peptone gave much the same results but with Evans peptone the gas production was $10 \cdot 8 \%$ with glucose. With the Aeromonas strains, the gas production was greater than $10 \%$ in all cases, except with filtered glucose when the amount was $9 \cdot 8 \%$. When the glucose was replaced by mannitol in the Difco peptone medium, 'B. salmonicida' produced a liquid displacement of $13 \cdot 6 \%$.

The results of the morphological, cultural, biochemical and metabolic tests are shown in Table 5. In addition to those shown, all the organisms produced acid from mannitol, maltose and fructose, but had no action on dulcitol and inulin; they were fermentative in Hugh \& Leifson's medium; methyl red negative; produced ammonia from peptone water; did not attack cellulose; grew in $1 \%$ but not in $8 \%$ salt (except for slight growth of strain 54); were resistant to penicillin, bacitracin, novobiocin, oleandomycin and 0-129; were sensitive to streptomycin and chloramphenicol and they all grew at $\mathbf{2 2}^{\circ}$.

\section{DISCUSSION}

The non-pigmented group (I) is very homogeneous (93.5-95.8\% similarity) and this is not surprising since all the strains came from the same source. Another set of cultures has now been examined and found to have the same reactions as those recorded here but the results could not be included in the computer analysis.

The next group (II) 'Bacterium salmonicida' is also extremely homogeneou s as, with the exception of 7 strains, the mean similarities lie between 90 and $94.6 \%$. This is particularly striking because the organisms were isolated from fish from Scotland, England, Ireland, Wales, Sweden and the United States, and from Salmo salar, S. trutta, S. gairdnerii, Coregonus pollan, Crassius auratus, Esox lucius, Oncorhynchus kisutch and $O$. tschawytscha. Further, the age of the culture does not appear to influence its properties as the NCTC culture had been isolated in 1954, whereas the others were mainly isolated in 1959 and 1960. The 7 exceptional strains, which have mean similarities of $\mathbf{8 7 - 9 0 \%}$, are not from any one source or species of fish, so that the strains of ' $B$. salmonicida' examined here cannot be separated into subgroups on the basis of source of specimen.

The Aeromonas strains were much more heterogeneous and can be divided into no less than 6 subgroups. These have, within themselves, quite a close similarity but these groups were not found to correlate with pathogenicity of the organisms or with the source of the specimen.

From the tables of results used in the computer analysis, it was possible to choose a typical strain for a group, i.e. a strain which has all the majority characteristics of the group. In the case of 'Bacterium salmonicida', one strain, 20, was found to have all the majority features so it is suggested that it be used as the neotype. It conforms to the description of ' $B$. salmonicida' given by Lehmann \& Neumann (1896) in that it is a non-motile, short rod, incapable of growth at $37^{\circ}$, able to produce a brown pigment in agar and liquefy gelatin, to grow on the surface and in the 
depth of solid media and to produce disease in salmonid fish. Strain 20 would therefore appear to be equivalent to the original 'B. salmonicida' strain.

Ewing et al. (1961) suggested ATCC 14174 as the neotype of the species and it was examined in this series where it was designated strain 34 . The strain was found to have a mean similarity of $89 \cdot 4 \%$ as compared with $94.52 \%$ for strain 20 and so did not have all the majority features of the group. In particular, strain 34 was found to be resistant to aureomycin, terramycin and tetracycline-a feature not recorded by Ewing et al. (1961). This resistance to the above antibiotics was only found with one other strain (36), and it suggests that these two strains had been isolated from a stock of fish which had been previously treated with antibiotics. Such strains would therefore be mutants rather than wild types so, for this reason, strain 34 was thought to be an unfortunate choice as the neotype.

Strain 20 along with strains of high $(92 \cdot 26)$ and low $(87 \cdot 2)$ similarities have been lodged with the National Collection of Marine Bacteria at Torry Research Station, Aberdeen, where they have been given the numbers Nсмв 1102, 1103 and 1104 respectively. (1103 is strain 2 and 1104 strain 28 of this series.)

When undisturbed cultures of newly isolated strains of 'Bacterium salmonicida' are examined in broth, the growth is found to resemble that of the streptococci in that the liquid is clear and flocculi are adhering to the sides of the test-tube. This macroscopic appearance is not so evident after subculture but it can be reproduced in laboratory cultures by incubation at $5^{\circ}$. Lehmann \& Neumann (1896) also record the similarity of ' $\mathrm{B}$. salmonicida' to the streptococci in its growth in broth, which remains clear except for a delicate growth on the walls of the test-tube near the surface of the liquid. Microscopic examination of liquid cultures of ' $B$. salmonicida' reveals a characteristic appearance. The non-motile cocco-bacilli are found to be in short chains and clumps composed of these chains. This appearance is in complete contrast to that of the motile Aeromonas strains where single or pairs of organisms are scattered at random over the field.

Culturally, 'Bacterium salmonicida' differs from the Aeromonas strains in its production of a brown water soluble pigment and in the friable nature of its colonies. This latter friability is stable over a large number of subcultures.

In previous descriptions of 'Bacterium salmonicida' or Aeromonas salmonicida, the organism has been described as producing very little gas from glucose (Arkwright, 1912) or as a gas producer (Griffin et al. 1953 a; Eddy, 1960, 1962; Ewing et al. 1961 ; Schubert, 1961). All the hundreds of strains of this organism isolated at the Marine Laboratory in the 9-year period 1953-62 produced very little or no gas from glucose but gave good gas production from mannitol. As gas production from glucose is a characteric feature of the aeromonads, the amount of gas present in the Durham tube was measured. Table 4 shows that ' $B$. salmonicida' produced a displacement of more than $10 \%$ only when Evans peptone was used in the medium. When the aeromonads are considered, it is noted that the greatest liquid displacement also occurred in the presence of Evans peptone but in this case the amount was $60 \%$. This represented a threefold increase in the amount of gas produced in the presence of Difco or Oxoid peptones. The corresponding increase for 'B. salmonicida' was about $\mathbf{0 . 5}$ so it would appear that ' $\mathbf{B}$. salmonicida' is not a vigorous gas producer. Buffered glucose was used to ascertain whether the lack of gas production was due to a decrease in the $\mathrm{pH}$ value of the medium inhibiting the fermentation process but 


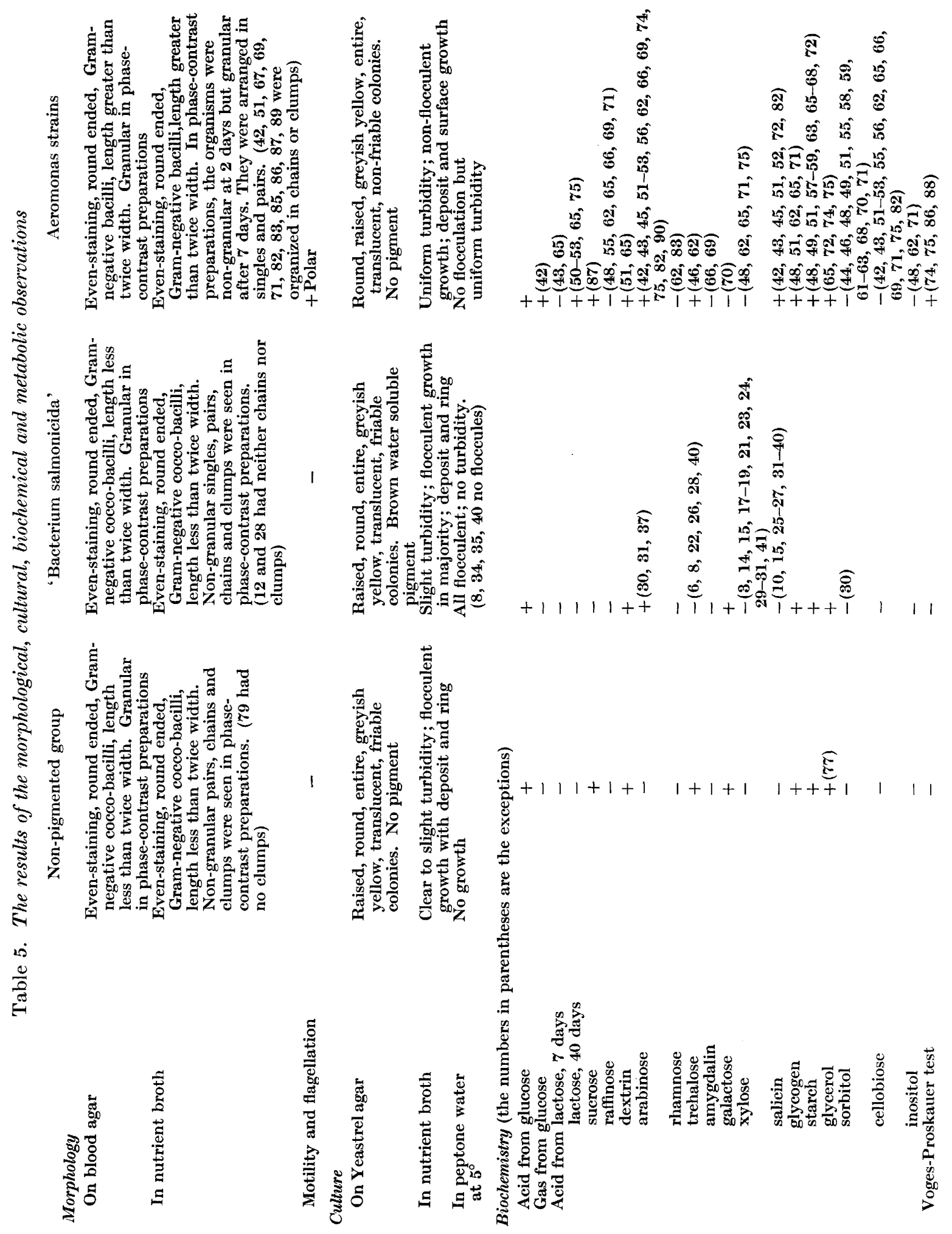




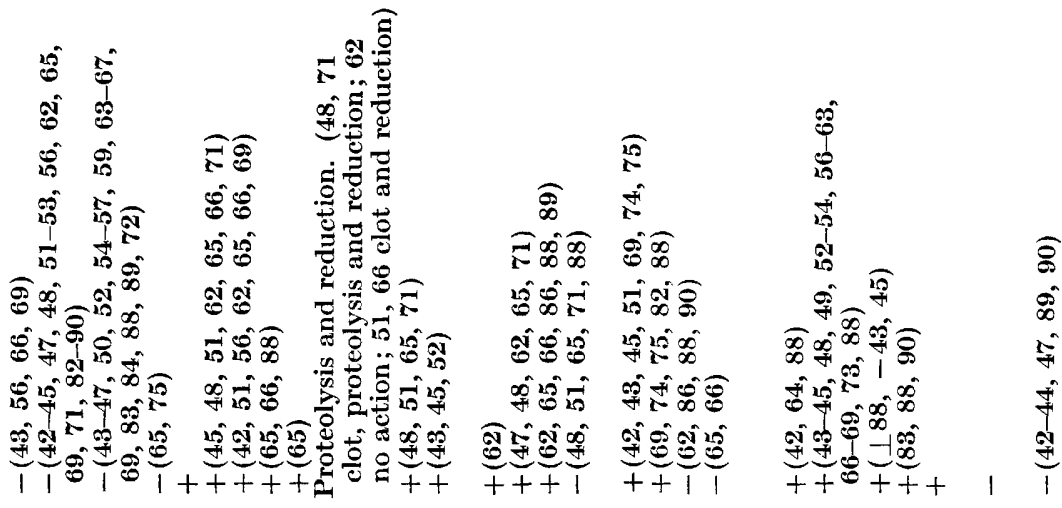

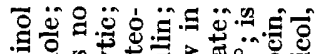

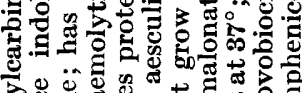

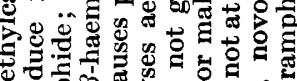

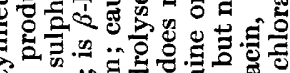

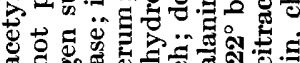
a

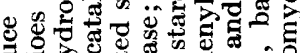

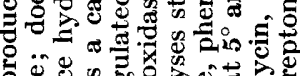
ڤิ巳

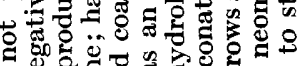

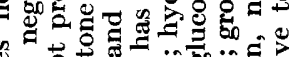

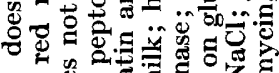

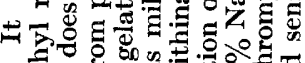

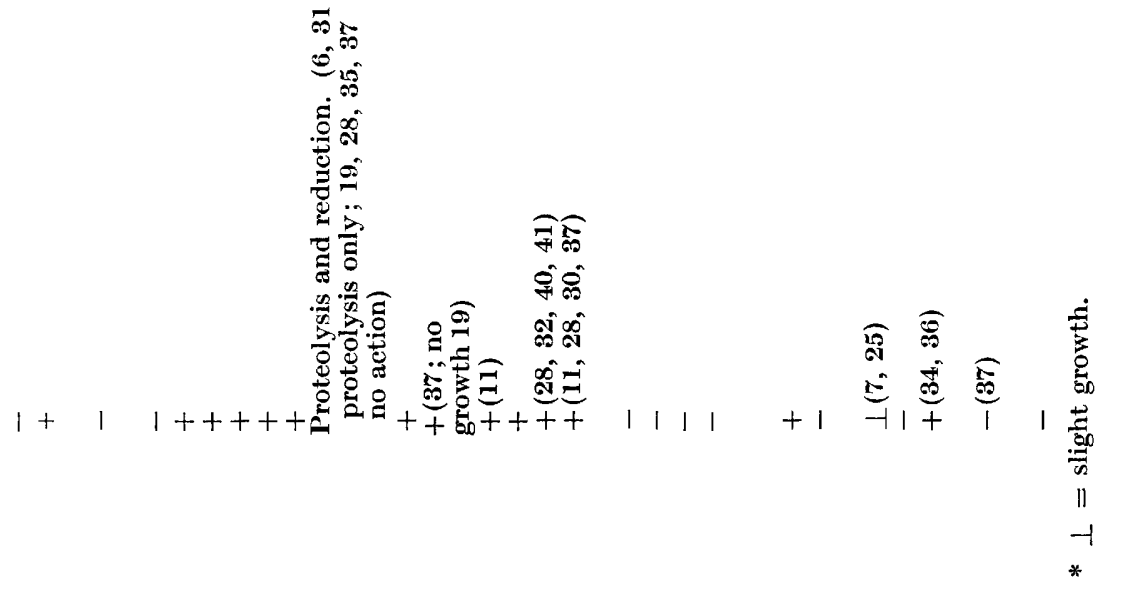

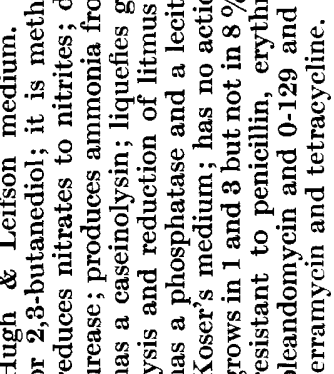

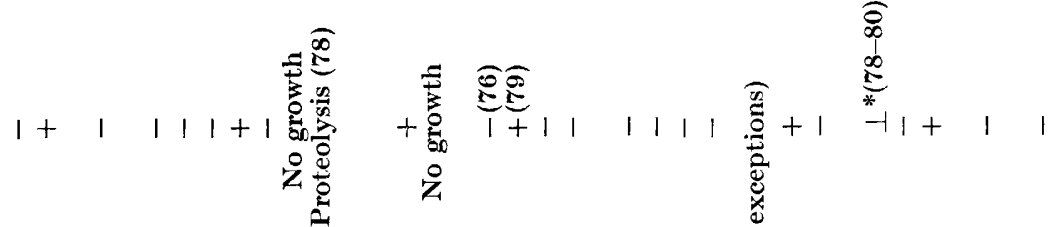

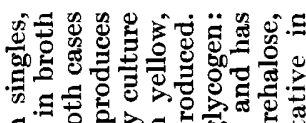

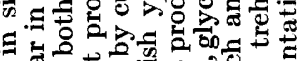

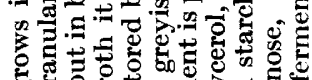
ơ

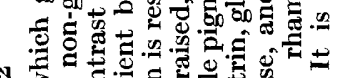

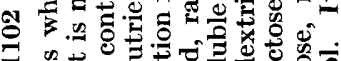

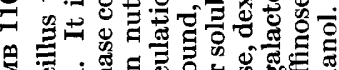

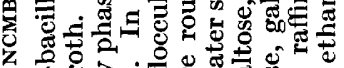

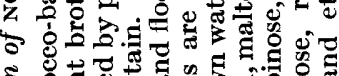
ร \&

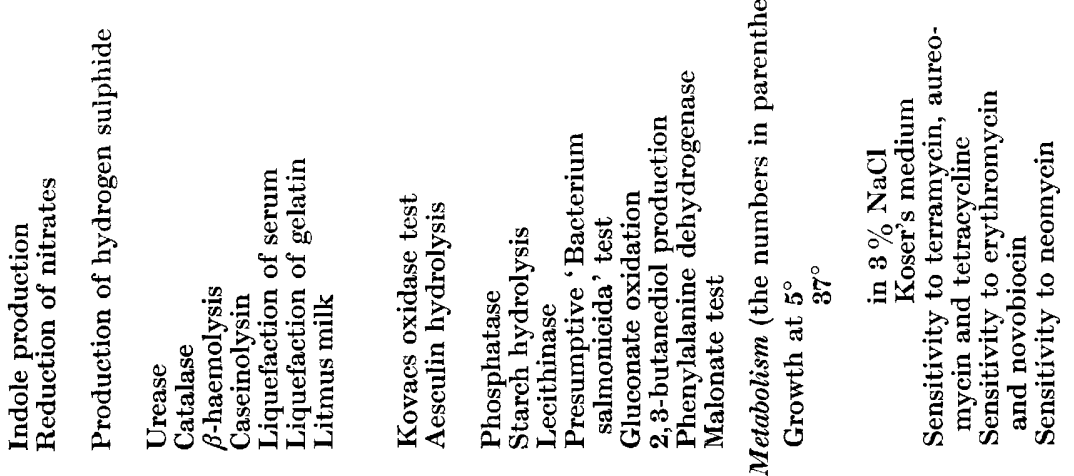

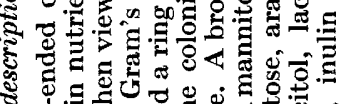
\$

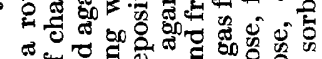
.2.

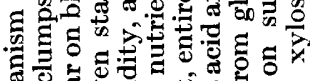

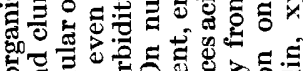

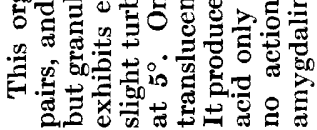


this was not so. The filtration of the glucose did not result in any increase in gas production so heating of the glucose did not have a detrimental effect on gas production. With Aeromonas strains it should be noted that even with Seitz-filtered glucose or buffered glucose the displacement of the liquid was $9 \cdot 8 \%$ or $10 \cdot 4 \%$ so that definite gas production would be recorded in almost every case. The results confirmed the fact that 'B. salmonicida' produced more gas from mannitol than from glucose.

In addition to an aeromonad being a vigorous gas producer, it is supposed to produce 2,3-butanediol from glucose. This characteristic has not been very assiduously applied to the genus in the past, probably owing to the lengthy procedure required to determine the compound. Bullock (1961) sugggested a very simple tube test employing piperazine and potassium ferricyanide after oxidation with potassium iodide; if the organism does produce 2,3-butanediol, a bright blue colour develops. This was tested on organisms which had been proved chemically to produce 2,3-butanediol. The results showed good correlation for both the known positive and negative species so this test was employed in the study. In not one of the non-pigmented group or of the 'Bacterium salmonicida' strains could the compound be detected nor did they produce acetylmethylcarbinol-the intermediate compound. This is not in agreement with Liu (1962), who stated that one strain of 'B. salmonicida' did produce 2,3-butanediol when tested by the method of Neish (1952). Of the 42 strains of Aeromonas, all but five $(69,74,75,82,88)$ produced 2,3-butanediol. Two of these strains $(69,82)$ did, however, produce the intermediate compound so the degradation of glucose may have been incomplete in these instances. By contrast, one strain, 86, appeared to have degraded the glucose completely as in this case no acetylmethylcarbinol was detected although 2,3-butanediol was present.

Griffin et al. (1953a) in their monograph, suggested that their results might justify transferring 'Bacterium salmonicida' to the genus Aeromonas, but they did not give any reason for this change, which has now been implemented (Snieszko, 1957). Eddy (1960, 1962) stated that A. salmonicida, despite its biochemical properties and lack of motility, should be retained in the genus Aeromonas but as a separate species. The present worker's results differ from those of Eddy $(1960,1962)$ in gas production from glucose, the fermentation of certain sugars and the phosphatase reaction. The findings of Ewing et al. (1961) differ from those given in this paper mainly in gas production and in fermentation of various sugars; these authors also found some phenylalanine dehydrogenase activity, weak or absent catalase activity and a positive methyl red test. They also thought that $A$. salmonicida warrants species rank but not that at present it should be removed from the genus Aeromonas. Schubert (1961) does not discuss the classification of A. salmonicida. He merely compares it with $A$. hydrophila and his results with the exception of the sugar reactions are in close agreement with those recorded here.

From the results of this survey, it can be seen that 'Bacterium salmonicida' differs from the Aeromonas strains in size, shape, configuration and lack of motility, in its friable colony and brown water soluble pigment formation, in its flocculent growth in broth, its weak gas production from glucose, in its lack of late acid production from lactose, in its ability to produce acid from sucrose, in its failure to produce acetylmethylcarbinol or 2,3-butanediol; in its ability to reduce nitrate 
to nitrite and in its inability to grow in Koser's medium. This means that, when Kluyver \& van Niel's definition (1936) is applied, 'B. salmonicida' could not be included in the genus Aeromonas owing to its lack of vigorous gas production, lack of motility and inability to produce 2,3-butanediol. Despite the fermentative nature of this organism, it appears to be more closely related to the Pseudomonadaceae than to the Enterobacteriaceae as it produces a water soluble pigment, is oxidase positive, does not produce acid from lactose, is unable to grow at $37^{\circ}$ and is highly proteolytic. It conforms to the definition of the family Pseudomonadaceae (Winslow et al. 1917) so it is suggested that a new genus be formed in the Pseudomonadaceae to accommodate ' $\mathrm{B}$. salmonicida' and its non-pigmented anaerogenic variant. As both the pigmented and the non-pigmented strains are capable of producing necrotic lesions and in some cases complete liquefaction of the internal organs of salmonids, the generic name Necromonas is proposed. This name is formed from the Greek noun necros a dead body and the Greek noun monas a unit. Necromonas would therefore be defined as M.L. fem. n. necrosis (producing) unit. To distinguish the non-pigmented strain from $N$. salmonicida the species name $N$. achromogenes is suggested.

Necromonas could be defined as a non-motile cocco-bacillus found in short chains and clumps of chains. It produces a friable colony and a brown water soluble pigment or no pigment on agar. In broth the growth is flocculent; it is oxidase positive; its action on glucose is fermentative but little or no gas accompanies the acid production; it does not produce 2,3-butanediol; it has no action on lactose, it is unable to grow at $37^{\circ}$ and it is a fish pathogen.

The author wishes to express her thanks to Dr J. M. Shewan and Mr C. R. Baines for helpful discussion and advice, to Mr K. A. Pyefinch for interest and encouragement, to Mr J. C. Gower for computing the results, to the donors of the organisms, to Mr J. D. Milne for the illustration and to Mrs W. Murray and Miss Jean MacGregor for valuable technical assistance.

\section{REFERENCES}

Arkwright, J. A. (1912). Report on the bacteriological examination of fish during the epidemic amongst salmon and trout in the summer of 1911. In MASTERman, A. J. (1912). Report...upon the epidemic amongst Salmonidae in the summer of 1911. Bd Agr. Fish. (1912), p. 6.

BARber, M. \& Kuper, S. W. A. (1951). Identification of Staphylococcus pyogenes by the phosphatase reaction. J. Path. Bact. 63, 65.

Bullock, G. L. (1961). A schematic outline for the presumptive identification of bacterial diseases of fish. Progr. Fish Cult. 23, 147.

Caselitz, F.-H. \& Günther, R. (1960). Weitere Beiträge zum Genus Aeromonas. $Z$ Zbl. Bakt. (1. Abt. Orig.), 178, 15.

Christensen, W. B. (1946). Urea decomposition as a means of differentiating Proteus and paracolon cultures from each other and from Salmonella and Shigella types. J. Bact. 52, 461 .

EDDy, B. P. (1960). Cephalotrichous, fermentative Gram negative bacteria, the genus Aeromonas. J. appl. Bact. 23, 216.

EdDy, B. P. (1962). Further studies on Aeromonas. I. Additional strains and supplementary biochemical tests. J. appl. Bact. 25, 137. 
Esselman, M. T. \& Liu, P. V. (1961). Lecithinase production by Gram-negative bacteria. J. Bact. 81, 939.

Ewivg, W. H., Hugh, R. \& Johnson, J. G. (1961). Studies on the Aeromonas group. U.S. Dep. of Health, Education, and Welfare, Communicable Disease Center, Atalanta, Georgia, U.S.A.

Griffin, P. J., Snieszko, S. F. \& Friddle, S. B. (1953a). A more comprehensive description of Bacterium salmonicida. Trans. Amer. Fish. Soc. 82, 129.

Griffin, P. J., Snieszko, S. F. \& Friddle, S. B. (1953b). A new adjuvant in the diagnosis of fish furunculosis by B. salmonicida. Vet. Med. 48, 280.

Hugh, R. \& Leifson, E. (1953). The taxonomic significance of fermentative vs. oxidative metabolism of carbohydrates by various Gram-negative bacteria. J. Bact. 66, 24.

Kluyver, A. J. \& van Niel, C. B. (1936). Prospects for a natural classification of bacteria. Zbl. Bakt. (Abt. 2), 94, 369.

Kovacs, N. (1956). Identification of Pseudomonas pyocyanea by the oxidase reaction. Nature, Lond. 178, 703.

Lemmann, K. B. \& Neumann, R. O. (1896). Atlas und Grundriss der Bakteriologie und Lehrbuch der speciellen bakteriologischen Diagnostik. Teil II, 240. München : J. F. Lehmann.

Liv, P. V. (1962). Fermentation reactions of Pseudomonas caviae and its serological relationship to aeromonads. J. Bact. $83,750$.

Mackie and McCartney's Handbook of Bacteriology (1960). 10th ed. Ed. by R. Cruickshank. Edinburgh: Livingstone.

Marsh, M. C. (1902). Bacterium truttae, a new bacterium pathogenic to trout. Science, 16, 706.

Neish, A. C. (1952). Analytical methods for bacterial fermentations. Rep. Nat. Res. Coun. Canada, no. 46-8-3, 2nd revision N.R.C. 2952.

Schubert, R. H. W. (1961). Über die biochemischen Merkmale von Aeromonas salmonicida. Zbl. Bakt. (Orig. 1), 183, 485.

Shaw, C. \& Clarke, P. H. (1955). Biochemical classification of Proteus and Providence cultures. J. gen. Microbiol. 13, 155.

Shewan, J. M., Hodgkiss, W. \& Liston, J. (1954). A method for the rapid differentiation of certain non-pathogenic, asporogenous bacilli. Nature, Lond. 173, 208.

Skerman, V. B. D. (1957). A key for the determination of the generic position of organisms listed in the manual. In Bergey's Manual of Determinative Bacteriology, 7th ed. London: Baillière, Tindall and Cox Ltd.

SNeATH, P. H. A. (1956). Cultural and biochemical characteristics of the genus Chromobacterium. J. gen. Microbiol. 15, 70.

Snieszko, S. F. (1957). Classification of Aeromonas. In Bergey's Manual of Determinative Bacteriology, 7th ed. London: Baillière, Tindall and Cox Ltd.

Topley and Wilson's Principles of Bacteriology and Immunity (1946). 3rd ed. Ed. by G. S. Wilson and A. A. Miles. London: Arnold.

Winslow, C-E. A., Broadhurst, J., Buchanan, R. E., Krumweide, C., Rogers, L. A. $\&$ Smith, G. H. (1917). The families and genera of the Bacteria. Family III. Pseudomonadaceae. J. Bact. 2, 555.

ZoBeld, C. E. \& Feltham, C. B. (1934). A comparison of lead, bismuth, and iron as detectors of hydrogen sulphide production by bacteria. J. Bact. 28, 169. 